\title{
THE STATE AND CONDITION OF HISTORICAL BUILDINGS LOCATED ON PARTISAN HILL IN WROCLAW
}

\author{
ANNA HOLA ${ }^{1}$, JERZY HOLA ${ }^{2}$, LUKASZ SADOWSKI ${ }^{3}$ AND JACEK \\ SZYMANOWSKI ${ }^{4 *}$ \\ ${ }^{1}$ Faculty of Civil Engineering \\ Wroclaw University of Science and Technology \\ Wybrzeże Wyspiańskiego 27, 50-370 Wroclaw, Poland \\ e-mail: anna.hola@pwr.edu.pl \\ ${ }^{2}$ Faculty of Civil Engineering \\ Wroclaw University of Science and Technology \\ Wybrzeże Wyspiańskiego 27, 50-370 Wrocław, Poland \\ e-mail: jerzy.hola@pwr.edu.pl \\ ${ }^{3}$ Faculty of Civil Engineering \\ Wroclaw University of Science and Technology \\ Wybrzeże Wyspiańskiego 27, 50-370 Wroclaw, Poland \\ e-mail: lukasz.sadowski@pwr.edu.pl \\ ${ }^{4}$ Faculty of Civil Engineering \\ Wroclaw University of Science and Technology \\ Wybrzeże Wyspiańskiego 27, 50-370 Wroclaw, Poland \\ e-mail: jacek.szymanowski@pwr.edu.pl (*corresponding author)
}

Keywords: Partisan Hill, historical buildings, state of preservation, non-destructive testing, seminon-destructive testing

\begin{abstract}
The paper presents fragments of original archival documentation, which are used to identify the historical outline of the colonnade building and the peristyle pavilion located on Partisan Hill in an old part of Wroclaw. Traces of these buildings date back to the Middle Ages. The state of preservation of these objects was presented on the basis of conducted assessments, drilling cores, and non-destructive and semi-non-destructive tests. Much attention was devoted to the brick walls, brick and reinforced concrete ceilings in flat roofs, as well as to the elements of architectural detail. The presented results include tests of the moisture content and salinity of walls, tests of the compressive strength of concrete and distribution of reinforcement in ceilings. They constitute the first stage of activities that aim to restore the buildings to their former glory.
\end{abstract}

\section{INTRODUCTION}

The purpose of the paper, apart from presenting a brief historical outline, is to present the current picture and condition of buildings erected in the 1860s and preserved to this day on Partisan Hill, which is located in an old part of Wroclaw, namely the colonnade building and 
the peristyle pavilion. The assessment was based on extensive research and analysis, which aimed to clarify conclusions and recommendations for the purpose of restoring the former splendour, not only of the buildings in question, but of the entire concept of Partisan Hill. So far, no renovation works have been carried out on Partisan Hill. The research described in the manuscript was first of a series of actions that are taken to restore the objects to their former glory.

It should be noted that Partisan Hill is a complex of great historical value. In 1967, it was included in the area of the urban complex of the Old Town of Wroclaw, which is in the register of monuments under the number: A/1580/212. The object itself, due to a decision of a conservation officer, was included in the register of monuments in 1970 under the number: A/2714/211. In turn, in 1994, by order of the President of the Republic of Poland, Partisan Hill was recognized as an historical monument (Fig. 1).

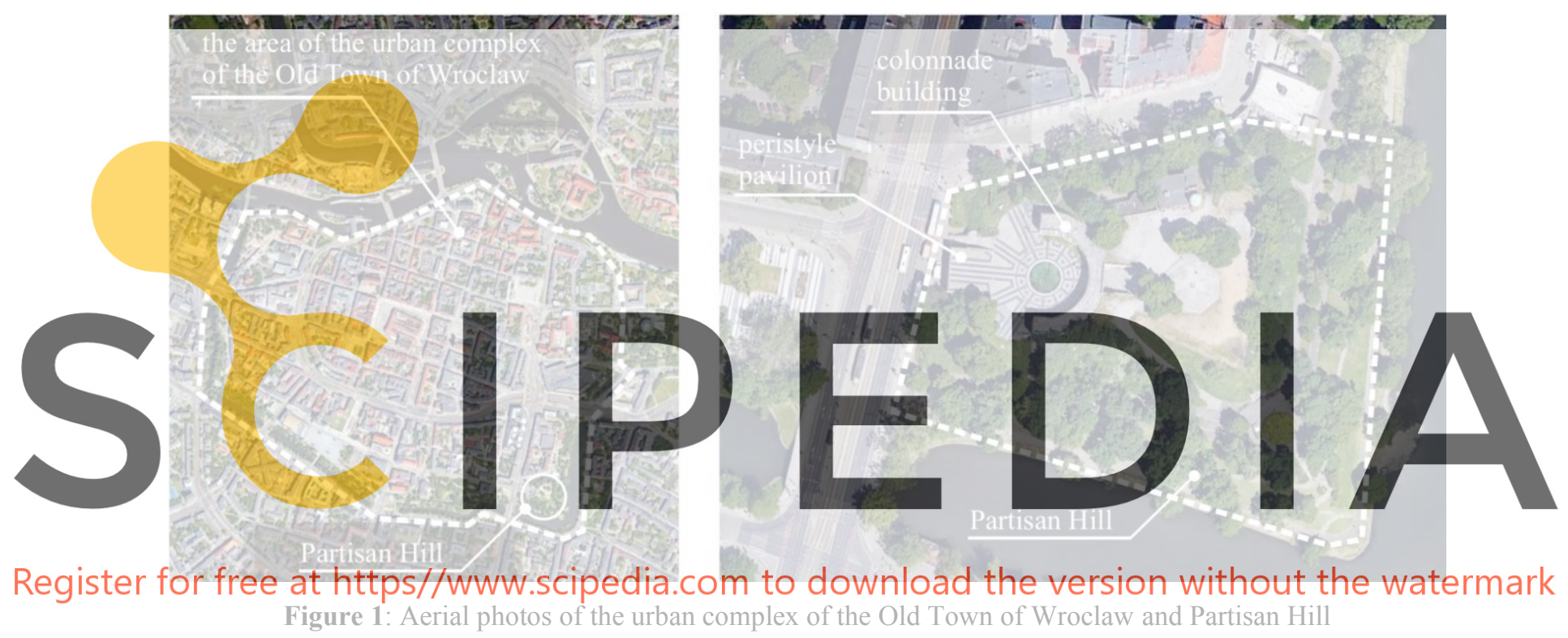

\section{HISTORICAL OUTLINE}

The first traces of the buildings of today's Partisan Hill date back to the Middle Ages, when in the area of the hill, then called Sakwowy Hill, a city gate was created that was called Sakwowa gate. In 1591, along with the extension and strengthening of the Wroclaw fortifications, a bastion designed by Hans Schneider was built on the hill.

During the liquidation of the city fortification system in the first decade of the 19th century, the bastion, as one of only a few buildings, was not demolished. Only military equipment was removed and the bastion was transformed into a viewing hill in a park complex that was called the Old Town Promenade, which was created in the area of former fortifications.

In the $1860 \mathrm{~s}$, the hill was developed with a complex of entertainment and recreation buildings that were founded by Adolf Liebich and designed by the architect Carl Schmidt. The complex included a belvedere standing on a plateau with a lookout tower, and also a colonnade building (Fig. 2a) and a peristyle pavilion (Fig. 2b), which were integrated into a terrace on the western slope of the hill. The peristyle pavilion was located at the foot of the 
hill, and it served as a mineral water pump room. On both sides of the pavilion, a wide staircase leading to the terrace was designed. In turn, a circular pool with a fountain was located in the centre of this terrace. From the east, the terrace was limited by a semi-circular loggia with stairs leading to the Belvedere palace, which was a central tower-like building designed on an octagonal plan and topped with a dome in which a confectionery was located. All the listed objects were in the style that correlates to the Italian Renaissance [1], and their mutual arrangement and location on the hill can be seen in digitized and generally available archival plans and maps [2].

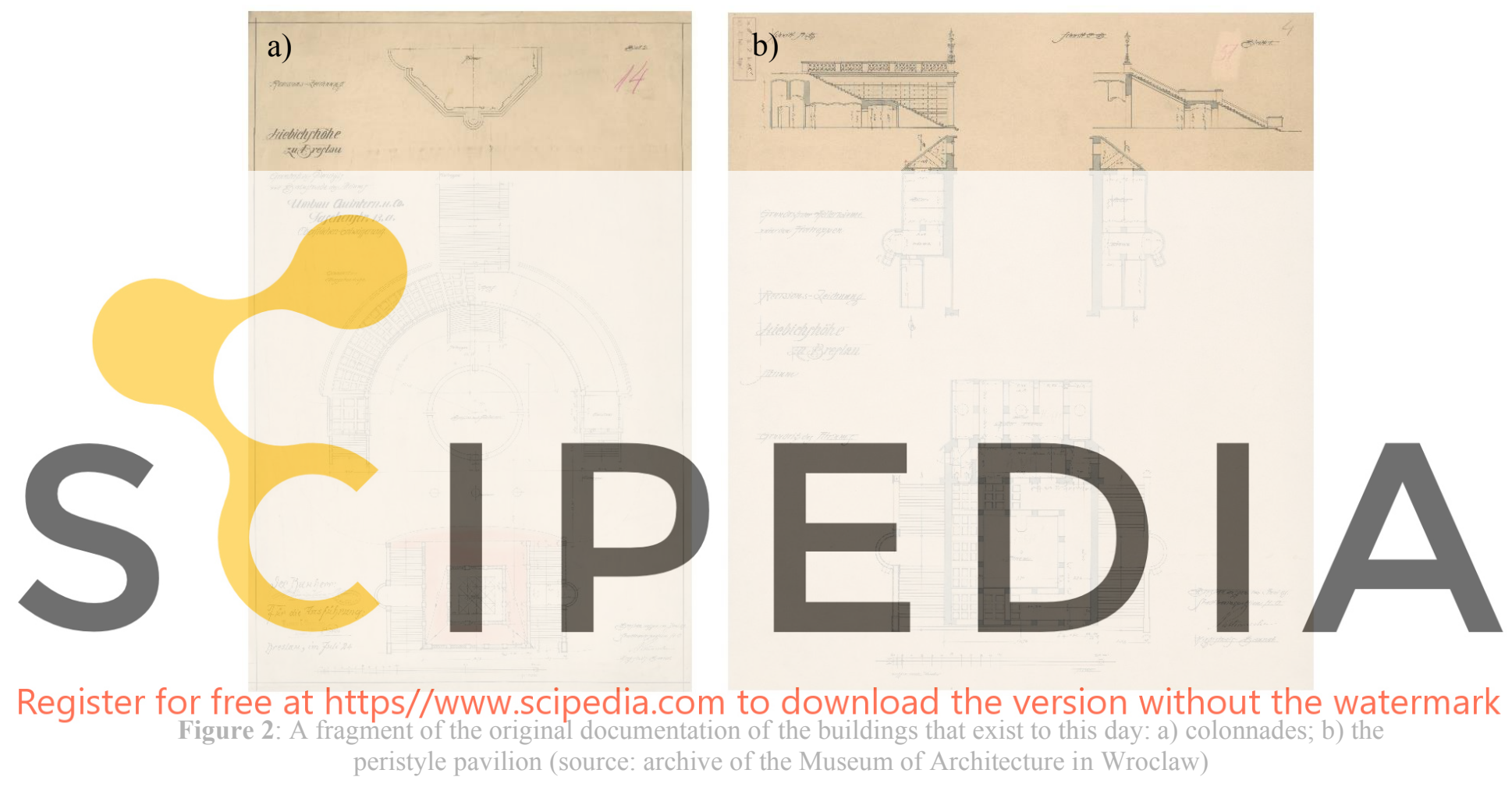

Major changes that refer to the architectural appearance and the way the buildings were used occurred in the 20th century. In the 1920 s, the peristyle pavilion was rebuilt and commercial premises were set up there. In the 1940s, due to the warfare conducted during World War II, anti-aircraft shelters were organized in the former casemates of the bastion, which later became the main defence headquarters of the city. The belvedere building was completely destroyed at that time.

In 1952, after the end of World War II, the municipal authorities of Wroclaw adopted the official name for the area in question - Partisan Hill - which has been operating to this day. In the period from the 1950 s to the 1990s, there were several unsuccessful attempts to revalorize the entire complex and restore its former glory. At that time, access to the buildings, i.e. the colonnade building and the peristyle pavilion, was temporarily suspended, and is now completely suspended due to their poor technical condition that threatens the health and life of people. 


\section{THE STATE OF PRESERVATION}

As mentioned in the introduction, the subject of the manuscript are all the buildings erected on Partisan Hill in the 1960s, which have survived to this day. Those are colonnade building and peristyle pavilion whose state of preservation has been described below.

\subsection{Colonnade building}

The colonnade building, which is shown in Figure 3, has two floors, one of which is mostly recessed in the ground. Its building area is about $460 \mathrm{~m}^{2}$. The walls of the lower floor are made of brick, and their thickness is in the range from 50 to $90 \mathrm{~cm}$. The flat roof based on them has a brick ceiling in the form of arched vaults with ribs (Fig. 3c). In turn, the ceiling of the above-ground floor is slab-ribbed and partly based on walls and partly on brick columns with a diameter of $50 \mathrm{~cm}$ (Fig. 3b). Both flat roofs were made in around 1870 and they are accessible directly from the area adjacent to the building

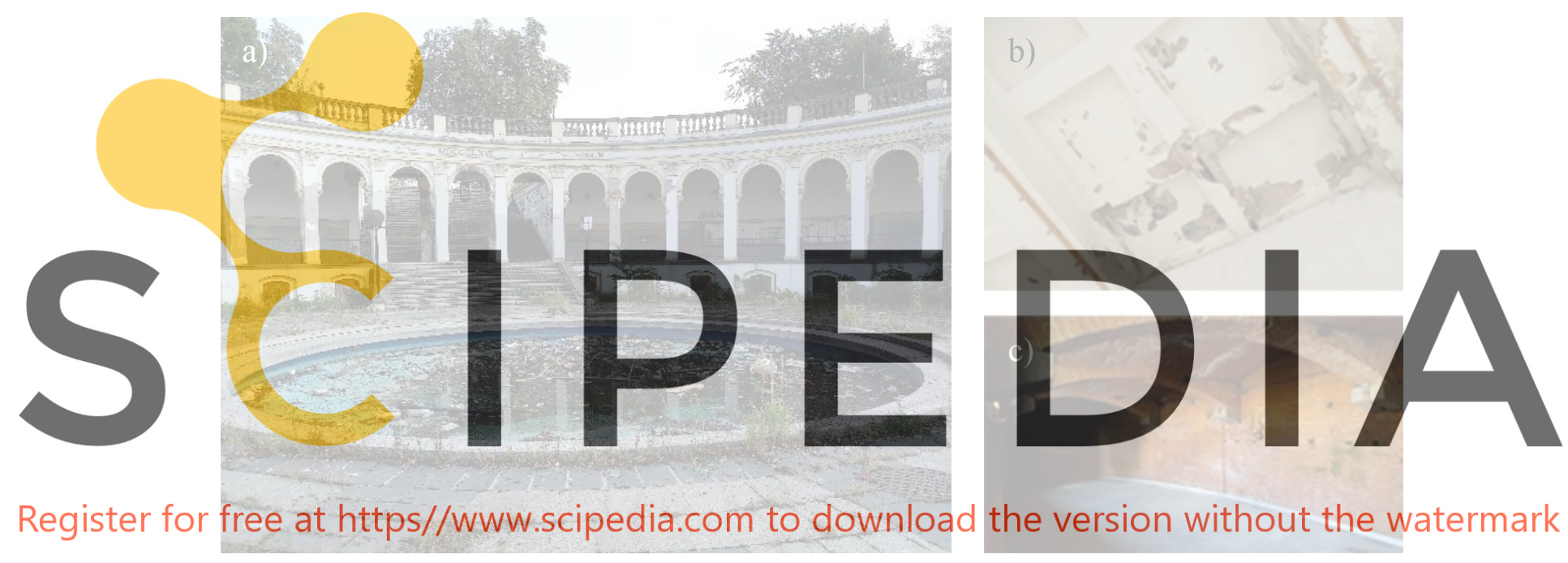

Figure 3: General view: a) the colonnade building (in the foreground is a swimming pool with a fountain); b) the slab-ribbed reinforced concrete ceiling; c) the basements and the brick ceiling

The brick construction elements of the basement, both the walls and the ceiling, are preserved in relatively good condition. They are free from significant damage in the form of wall cracks and deformations of arched vaults and ribs. However, they are very moist and covered with salt efflorescence and mold fungi. This is the result of a lack of vertical and horizontal damp-proof insulation, which was proved by the executed exposure works of the walls. In addition, due to excessive moisture, these elements have local losses of brick fragments and numerous places with crumbling of the mortar between the bricks.

The brick elements of the above-ground structure, in particular its columns, are in a similar condition. They are also damp and show mortar crumbling between bricks on surfaces that are partially free of plaster. The reinforced concrete ceiling of the roof is also very damp. Its bottom surface shows numerous patches of corrosion in its reinforcement (Fig. 4b). 
Elements of architectural detail, such as e.g. posts, balusters, the stucco decorations of arches and column heads, plasters, and also granite flooring are incomplete, damaged, or completely damaged, as illustrated in Figure 4.
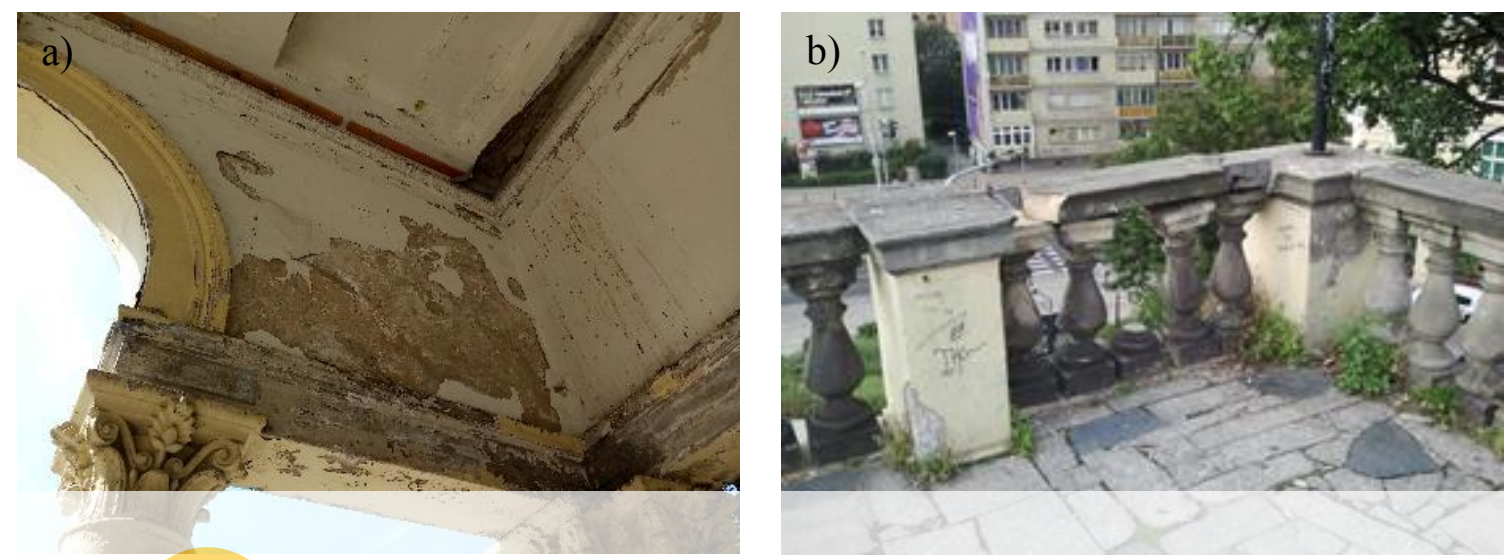

Figure 4: View: a) damage to stucco and plasters in the colonnade building; b) incomplete elements of the balustrade and granite floor

In both flat roofs of the colonnade building, semi-non-destructive testing was performed by taking core samples with a diameter of $100 \mathrm{~mm}$ in order to determine the layout of layers and their thicknesses. The places of taking samples, as well as the obtained core specimens, are shown in Figures 5 and 6. In the layput of the layers in the flat roofs above the floor embedded in the ground, which is shown in Figure 5, the lack of danp-proof ins noteworthy. In the layout of the layers of the flat roof above th seen several layers of concrete with different thickness, a laye layer of mortar and granite slab all laid on rein

Register for free at https//www.scipedia.com to download the version without the watermark

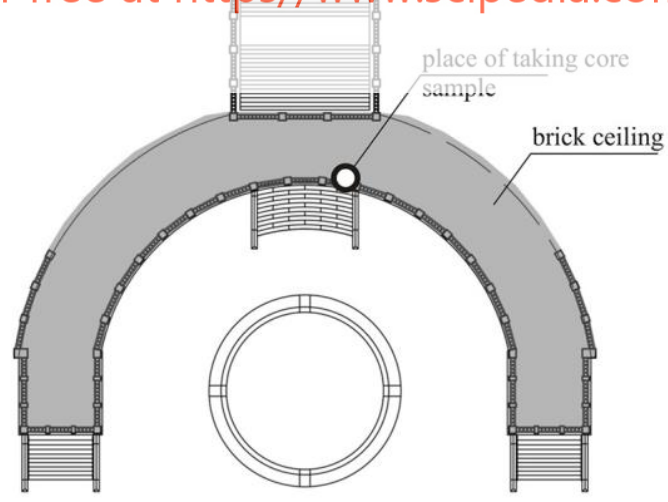

scale $1: 750$

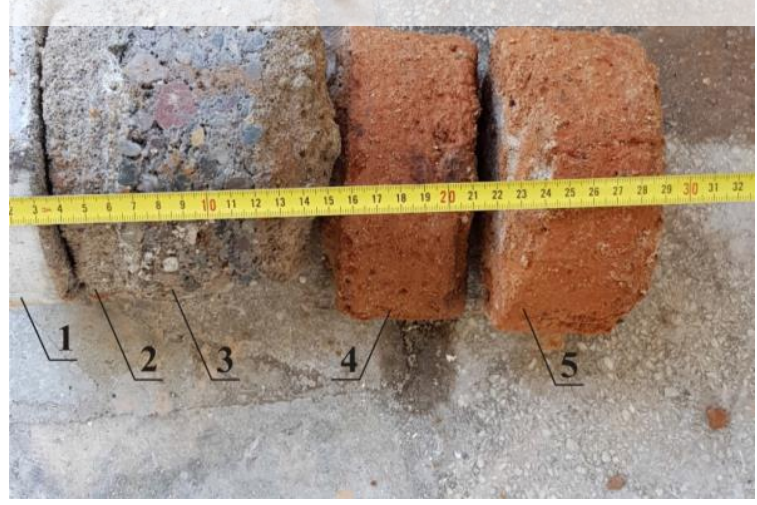

Figure 5: Colonnade building: a) place of taking core samples in the flat roof above the floor embedded in the ground; b) flat roof system: 1 - granite slab with a thickness of $30 \mathrm{~mm}, 2$ - cement mortar with a thickness of 40 $\mathrm{mm}, 3$ - concrete with a thickness of $100 \mathrm{~mm}, 4$ - brick vault with a thickness of $120 \mathrm{~mm}$ 

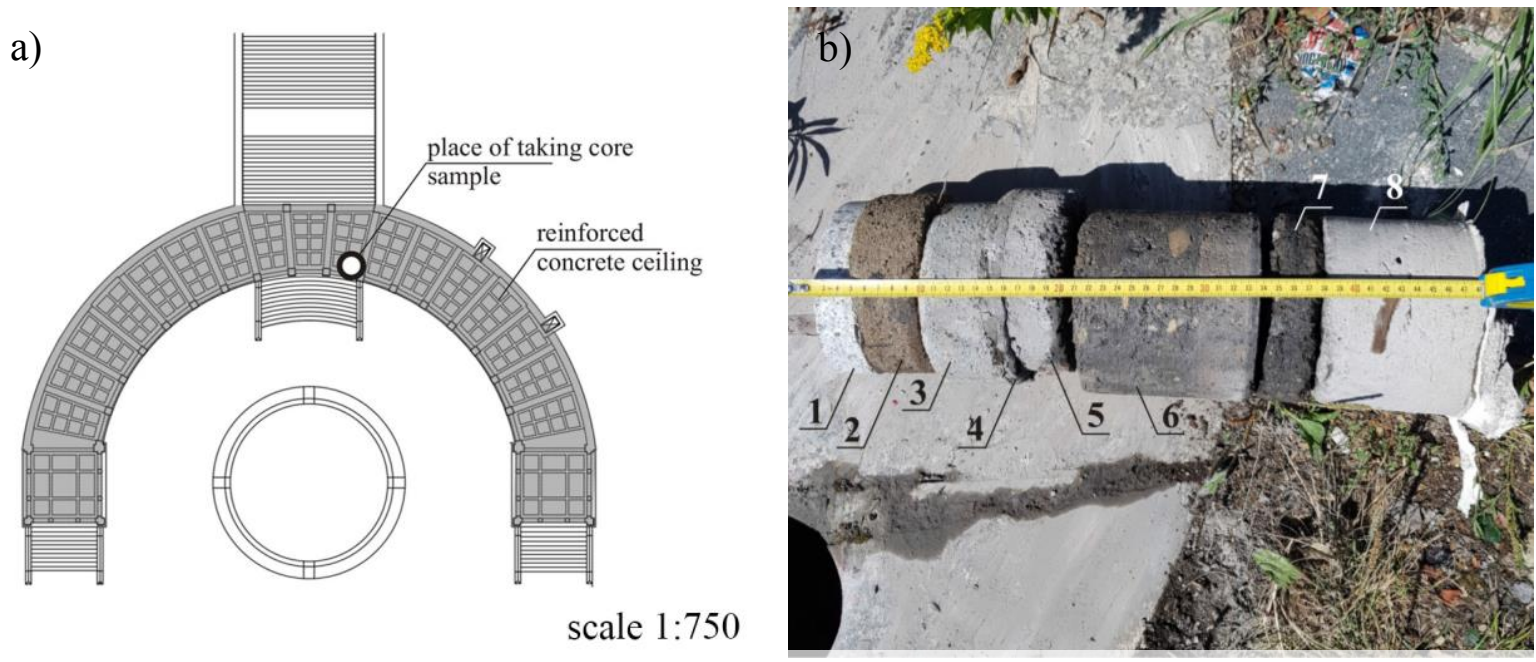

Figure 6: Colonnade building: a) place of taking core samples in the flat roof above the ground floor; b) flat roof system: 1-granite slab with a thickness of $30 \mathrm{~mm}, 2$ - cement mortar with a thickness of $45 \mathrm{~mm}, 3$ - concrete with a thickness of $55 \mathrm{~mm}$, 4- bituminous insulation with a thickness of $5 \mathrm{~mm}, 5$ - concrete with a thickness of $40 \mathrm{~mm}, 6$ - concrete with a thickness of $120 \mathrm{~mm}, 7$ - concrete with a thickness of $30 \mathrm{~mm}, 8$ - reinforced concrete ceiling slab with a thickness of $100 \mathrm{~mm}$

\subsection{Peristyle pavilion}

The peristyle pavilio one side completely, an 7a. Its external and inter
$\mathrm{cm}$. Inside the pavilion, walls, as well as brick c a)

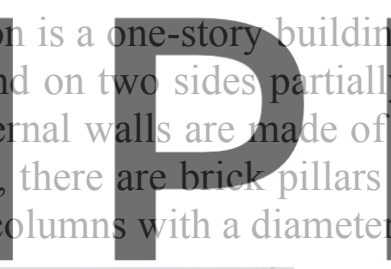

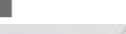

Register for free at https//www.scipedia.com to download the version without the $1: 450$ watermark
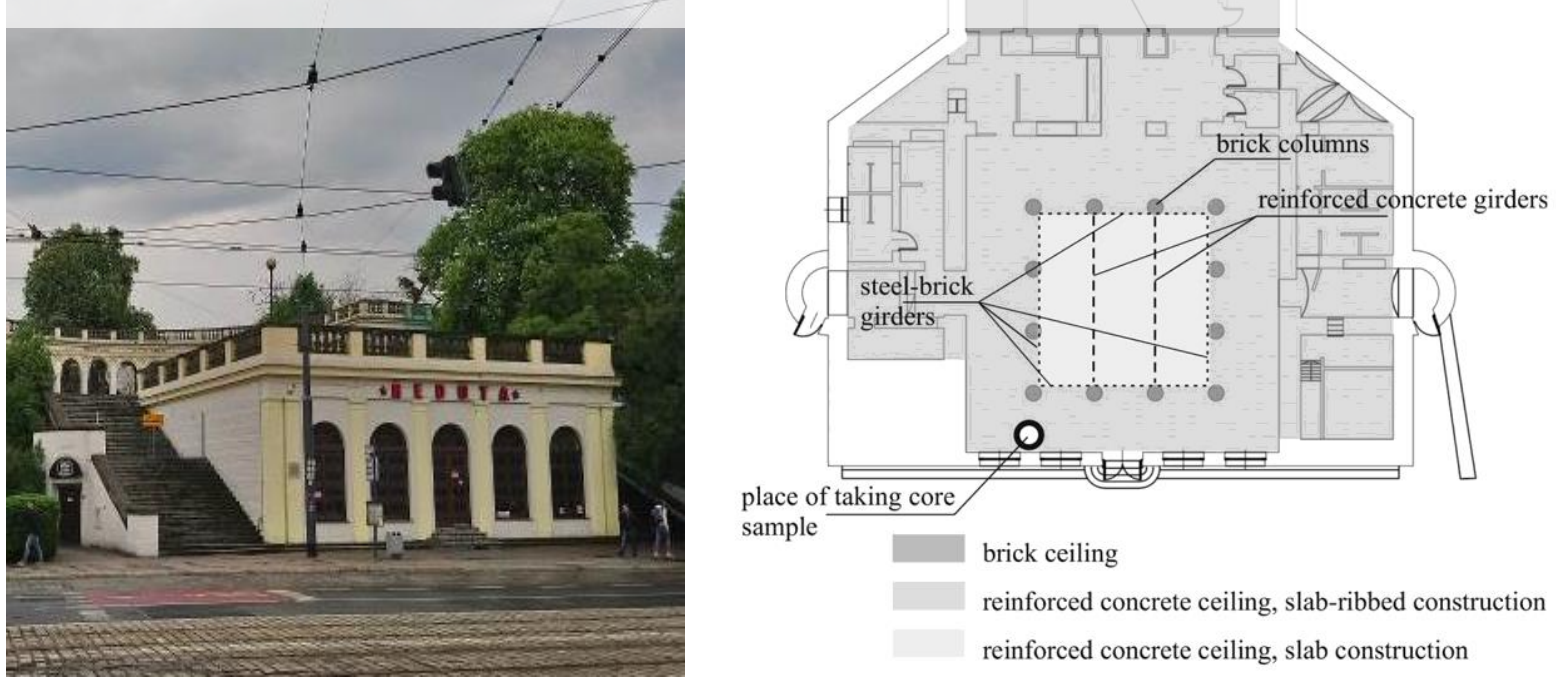

Figure 7: Peristyle pavilion: a) view of the building; b) scheme of the projection with marked structural elements 
The pavilion's ceiling is directly accessible from the adjacent area. It has a reinforced concrete, partly slab-ribbed, and partly slab construction, while the girders are reinforced concrete or steel-brick. On a small fragment there is also a brick ceiling. The layout of the specified structural elements is shown in Figure $7 \mathrm{~b}$.

The brick constructional elements of the pavilion, as is the case with the colonnade building, are preserved in relatively good condition. However, they are very damp and covered with salt efflorescence and mold fungi (Fig. 8). The execution of the exposures showed that neither vertical nor horizontal damp proof insulation was executed in this building. The mortar in the joints between the bricks is crumbing, and in some places reaches a depth of up to several centimetres.
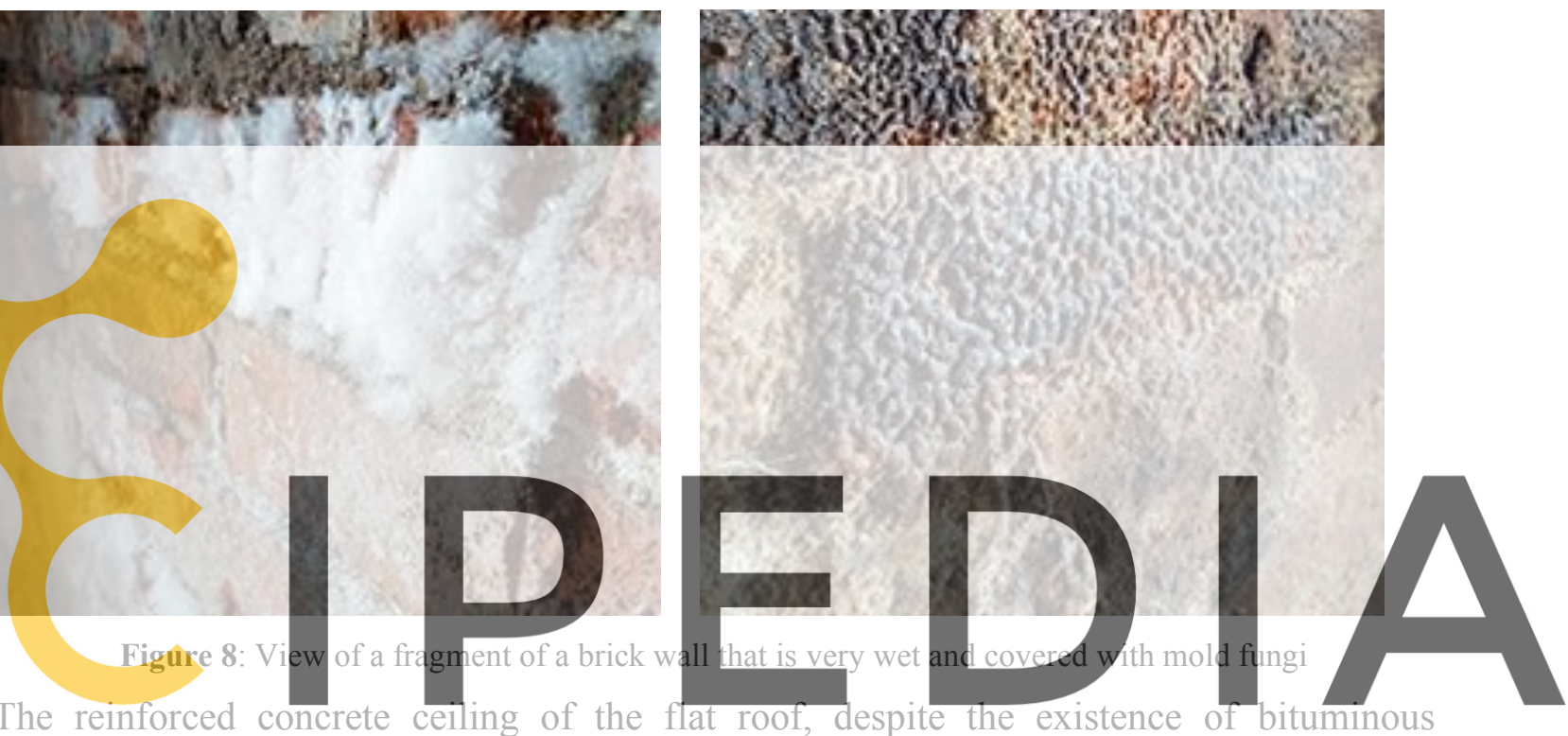

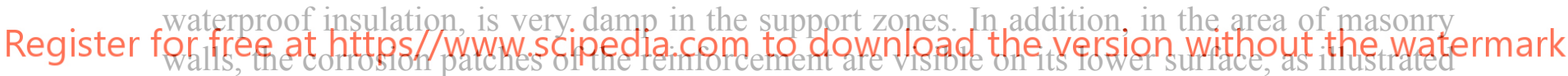
in Figure 9. In this flat roof, semi-non-destructive testing was performed in order to take a core sample. The layout and layer thicknesses were found to be the same as those in the fiat roof above the ground floor in the colonnade building.
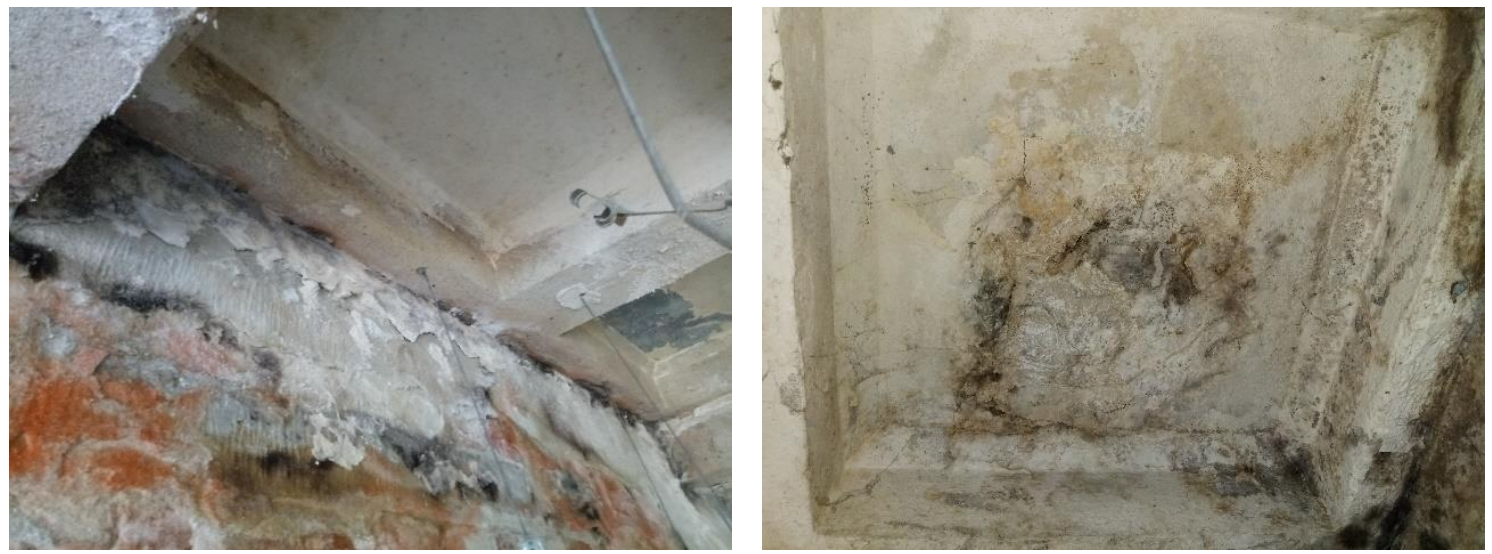

Figure 9: Sample view of moisture and patches of corrosion of a reinforced concrete ceiling 


\section{RESULTS OF CONDUCTED TESTS AND ANALYZES}

Due to the limited volume of the paper, it is not possible to present full descriptions of the conducted tests and their detailed results, as well as computational analyzes that were based on them. For this reason, only the most important conclusions are presented in the further part of the paper.

\subsection{Results of the tests of the moisture content and salinity of the brick walls}

The moisture content tests were performed using the weighing method and the nondestructive dielectric method (Fig. 10). It was found that in both buildings, the brick walls that are covered with soil from the outside are wet, because according to the classification adopted in literature $[3,4,5]$, their mass moisture content along the entire height exceeds $12 \%$. In the case of the internal walls, pillars, and columns, a similar situation occurs up to a height of about $50 \mathrm{~cm}$ above the floor level. Above $50 \mathrm{~cm}$ to a height of almost $100 \mathrm{~cm}$, the brick walls are very and moderately damp, with their moisture content being in the range of $12 \%$ to 5\%.
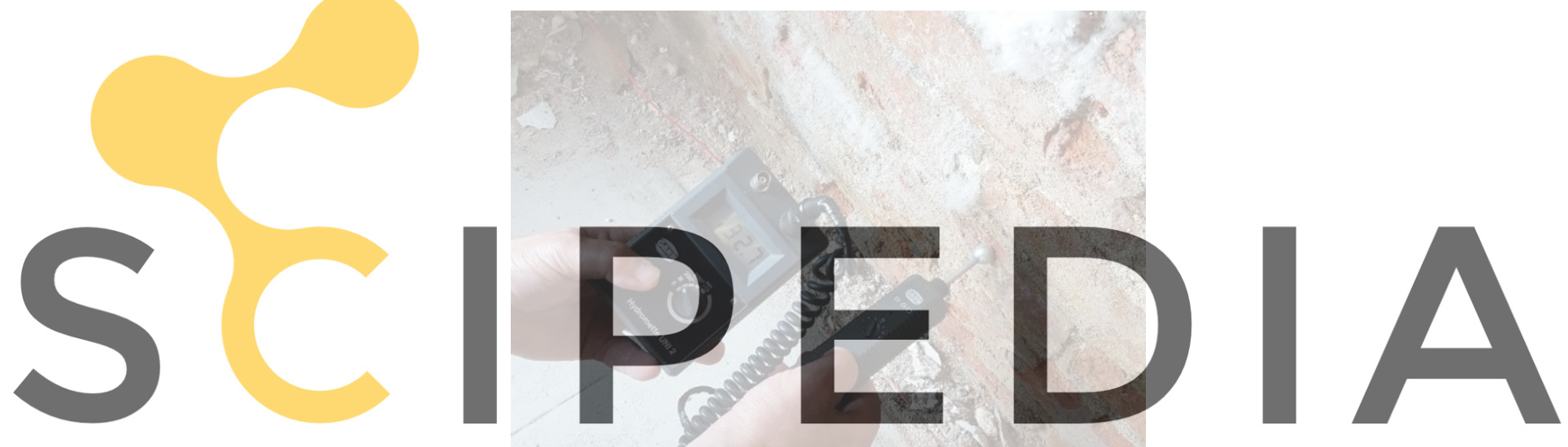

Register for free at https//www.scipedia.com to download the version without the watermark

Figure 10: Examination of the moisture content in a brick wall using the dielectric method

The salinity tests of the brick walls were carried out using the semi-quantitative method, and it showed that the limit concentration of sulphate salts, which according to the classification adopted in literature is $0.5 \%[3,4,5]$, is exceeded more than two times.

\subsection{Test results of the ceilings in the flat roofs}

Concrete compression strength tests in the reinforced concrete ceilings were carried out using the non-destructive sclerometric method. The regression curve was assumed based on [6]. The minimum compressive strength evaluated based on this method was $22 \mathrm{MPa}$ and this concrete was classified as being C20 / 25 class.

Tests on the distribution of steel in the reinforced concrete ceiling elements, slabs, ribs and girders were carried out using the non-destructive electromagnetic method and then verified by executing the exposure works. It was found that the reinforced concrete slabs are reinforced with $12 \mathrm{~mm}$ smooth bars with a spacing of $150 \mathrm{~mm}$, whereas the reinforced 
concrete girders are reinforced with ribbed bars $\varnothing 22 \mathrm{~mm}$ that are spaced every $60 \mathrm{~mm}$. In turn, the reinforcement of the steel and brick girders consists of a flat bottom rail with a height of $149 \mathrm{~mm}$ [7].
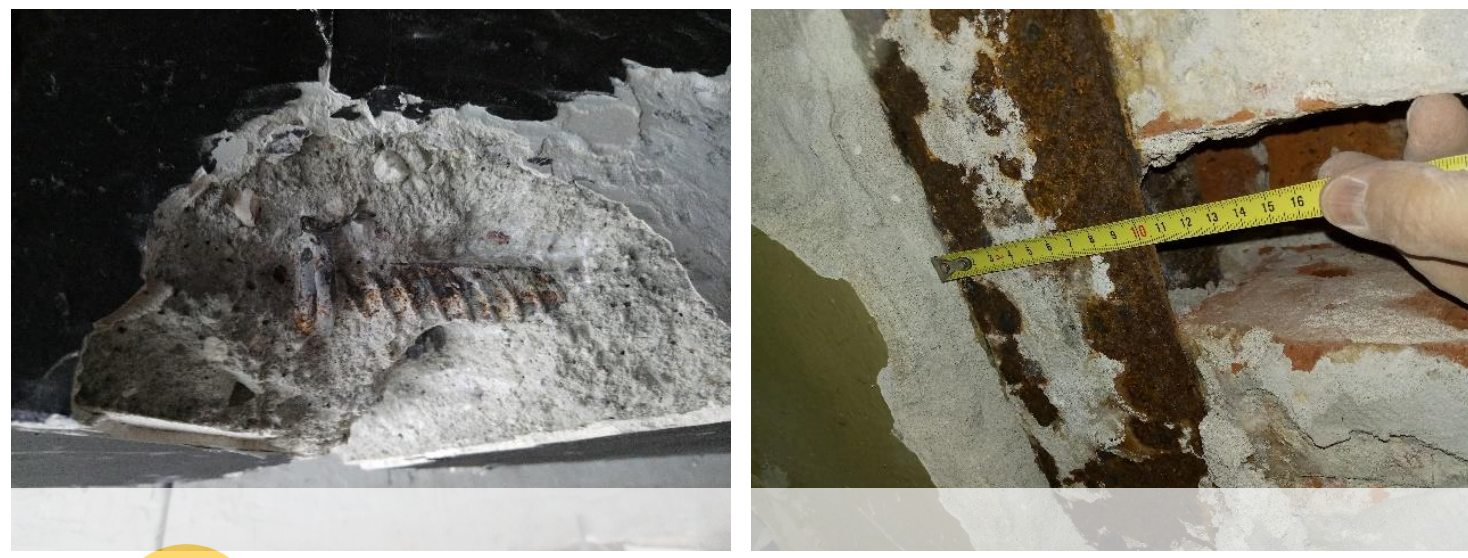

Figure 11: Exemplary view of: a) reinforcement in a reinforced concrete girder; b) flat bottom rail's foot

\section{SUMMARY}

The paper presents the current state and condition of the historic buildings located on Partisan Hill in Wroclaw, namely the colonnade buildings and the peristyle pavilion that have involved the uise of execution of control exp

The above works we former splendor of the from the conducted tesearch and analyzes no

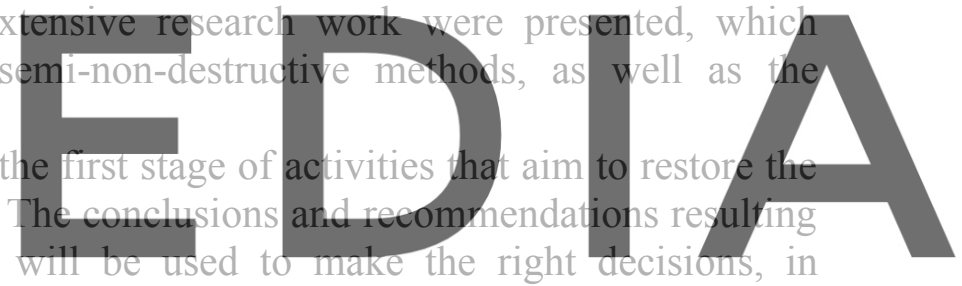
consultation with the conservator, regarding the scope and method of renovation and

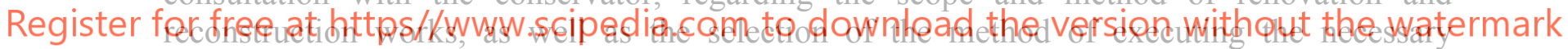
reinforcements of the structural elements.

\section{REFERENCES}

[1] Tomaszewicz A., Żurek A. Partisan Hill. In: R. Eysymontt et al. (Eds.): Leksykon architektury Wrocławia, Wydawnictwo Via Nova, Wroclaw (2011), pp.331-332.

[2] www.fotopolska.eu/Wzgorze_Partyzantow_Bastion_Sakwowy_Wroclaw (dostęp 02.01.2020).

[3] Rokiel M. Hydroinsulations in the construction industry (in Polish). Grupa MEDIUM, Warsaw (2006).

[4] Hoła A. Measuring of the moisture content in brick walls of historical buildings the overview of methods. In: 3rd International Conference on Innovative Materials, Structures and Technologies (IMST 2017), Riga, Latvia. [Bristol]: IOP Publishing (2017).

[5] Hoła J. Degradation of historic buildings due to excessive moisture (in Polish). In: Budownictwo i Architektura (2018) vol. 17(1), pp.133-148.

[6] Runkiewicz, L. Testing of Concrete Structures (in Polish); Biuro Gamma: Warszawa (2002). 
[7] Czapliński K. Old iron alloy products (in Polish). Dolnośląskie Wydawnictwo Edukacyjne, Wroclaw (2009).
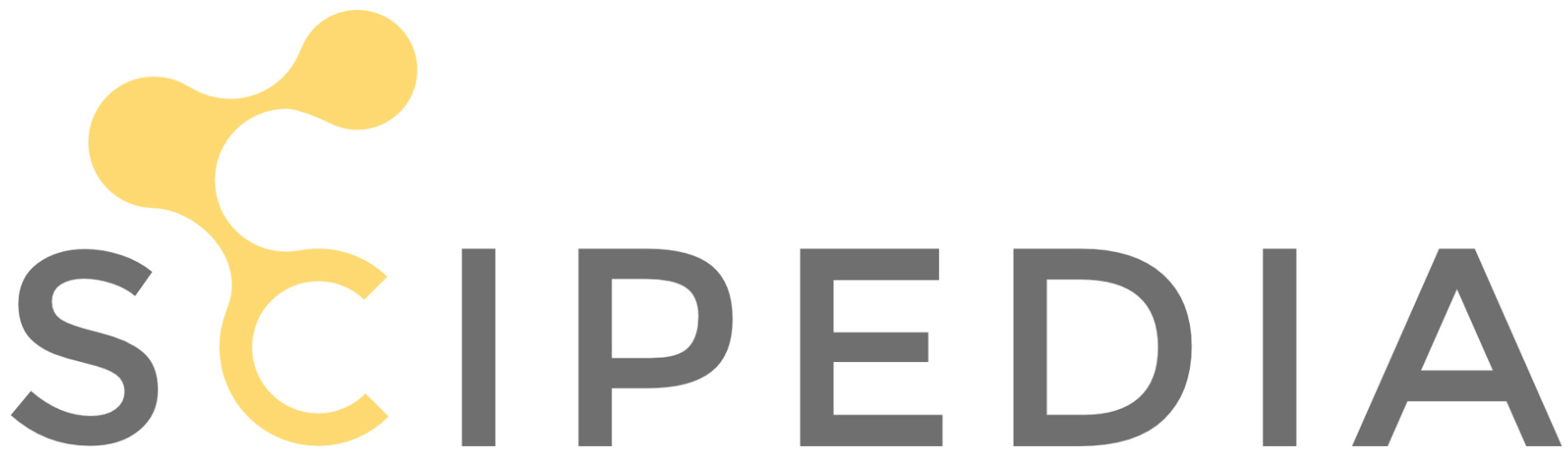

Register for free at https//www.scipedia.com to download the version without the watermark 